\title{
Improved Sample Preparation Methodology on Lime Mortar for Reliable ${ }^{14} \mathrm{C}$ Dating
}

\author{
Luis Angel Ortega ${ }^{1}$, Maria Cruz Zuluaga ${ }^{1}$, Ainhoa Alonso-Olazabal ${ }^{1}$, \\ Maite Insausti2 ${ }^{2}$ Xabier Murelaga ${ }^{3}$ and Alex Ibañez ${ }^{4,5}$ \\ ${ }^{1}$ Mineralogy and Petrology Department, \\ 2Inorganic Chemistry Department, \\ ${ }^{3}$ Stratigraphy and Palaeontology Department, Science and Technology School, \\ ${ }^{4}$ Social Sciences Department, School of Education, \\ The University of the Basque Country, \\ ${ }^{5}$ Historical Archaeology Department, Aranzadi Society of Science, \\ Spain
}

\section{Introduction}

Dating ancient buildings and establishing construction phases are important issues for archaeologists and cultural heritage researchers alike. When using radiometric dating to this end, the fundamental requirement consists in acquiring suitable datable material that records the age of the studied object.

Plaster and mortar are composite building materials comprising a mixture of binder and aggregates. Binders in archaeological buildings consist of lime and gypsum, whereas aggregates contain inorganic and organic materials (Sickels, 1981). The most common organic component is charcoal, most likely corresponding to residues of the burning process, especially when a continuous wood-fired kiln was used.

Up until now, building lime, sand, pottery, and organic materials from mortars have been used in dating (Folk \& Valastro, 1976; Tubbs \& Kinder, 1990; Heinemeier et al., 1997a; Schmid, 2001; Goedicke, 2003; Hale et al., 2003; Benea et al., 2007; Lindroos et al., 2007; Wintle, 2008). Organic materials are widely used to date mortar and plaster (Berger, 1992; Van Strydonck et al., 1992; Frumkin et al., 2003; Rech et al., 2003; Rech, 2004; Wyrwa et al., 2009; Al-Bashaireh \& Hodgins, 2011) where no other easier datable material is present, such as written inscriptions, coins, and/or historical records (see Heinemeier et al., 1997b; Hale et al., 2003; Heinemeier et al., 2010). Tubbs and Kinder (1990) reported the unreliability of dating mortar based on organic inclusions because of the old wood problem. Recently, Heinemeier et al. (2010) have presented extensive examples of the same problem and also reached the same conclusion.

The lime mortar binder represents an often-used tool to assess the chronology of the different construction phases of buildings by means of radiocarbon dating. The principle of radiocarbon dating is that binder carbonates absorb carbon dioxide from the atmosphere, 
thus making mortars potentially suitable for ${ }^{14} \mathrm{C}$ dating. The basis of mortar dating can be summarized as follows: limestone (mainly $\left.\mathrm{CaCO}_{3}\right)$ is burned to lime $(\mathrm{CaO})$ and this calcium oxide is then slaked with water to form portlandite $\left(\mathrm{Ca}(\mathrm{OH})_{2}\right)$. The calcium hydroxide is mixed with sand and water to make the building mortar and, during hardening, the lime mortar absorbs carbon dioxide $\left(\mathrm{CO}_{2}\right)$ from the atmosphere to produce calcium carbonate $\left(\mathrm{CaCO}_{3}\right)$. During the hardening process, the actual ${ }^{14} \mathrm{C}$ concentration of $\mathrm{CO}_{2}$ in air is fixed to the binder carbonate.

The method of radiocarbon dating has been applied since the 1960s (Labeyrie \& Delibrias, 1964; Stuiver \& Smith, 1965; Baxter \& Walton, 1970; Van Strydonck et al., 1983; Van Strydonck et al., 1986; Ambers, 1987; Van Strydonck et al., 1992; Heinemeier et al., 1997a; Hiekkanen, 1998; Hale et al., 2003; Nawrocka et al., 2005; Lindroos et al., 2007; Nawrocka et al., 2007; Nawrocka et al., 2009; Heinemeier et al., 2010; Marzaioli et al., 2011), but frequently the isotopic age and the expected historic age differ, with the former providing older dates.

In dating building mortars, problems to obtain the correct age are common, often related to an adequate selection of binder carbonate. Unfortunately, most lime samples contain carbons of different provenances: incompletely burned limestone fragments, charcoal particles from wood-fired kilns, and aggregates. Aggregates are mainly natural sands. Depending on the geological and geographical location, it may also contain carbonate minerals, carbonate rock fragments, and calcareous fossils. So, the aggregates primarily constitute an additional source of contamination in carbon. Other potential problem in mortar dating is related to the hardening process. In view of the radio-chronological results some authors suggest that mortar lying on the inside of walls or behind stone facing can take years and decades (Van Strydonck \& Dupas, 1991) and even centuries for voluminous structures (Sonninen et al., 1989) before the whole construction has carbonated. Thus yielding a date that is too young for the building as a whole. However, based on experimental works the hardening process of a mortar is relatively rapid compared with the half-life of ${ }^{14} \mathrm{C}$ (Pachiaudi et al., 1986; Lanas et al., 2005; Stefanidou \& Papayianni, 2005; Kosednar-Legenstein et al., 2008; Ball et al., 2011). According to these researches the hardening is completed within weeks or months. Since the binder phase is constituted of small calcite grains (e.g. Stefanidou \& Papayianni, 2005; Zamba et al., 2007; Ball et al., 2011; Marzaioli et al., 2011), an accurate selection of adequate lime grain-size fraction allows to date this rapid carbonation reaction.

Therefore, in order to eliminate these error sources, sample preparation procedures have been improved upon since the beginning of radiometric method dating. Most of these preparations consist of mechanical pre-treatment and chemical treatment (Sonninen \& Jungner, 2001; Lindroos et al., 2007; Nawrocka et al., 2007; Goslar et al., 2009; Nawrocka et al., 2009; Heinemeier et al., 2010).

In mechanical separation, the mortar samples are gently broken and then sieved (different sized meshes are used). Van Strydonck et al. (1992) used a $250 \mu \mathrm{m}$ sieve, whereas others (Heinemeier et al., 2010 and references therein) utilized an increasingly fine mesh ranging between $20-500 \mu \mathrm{m}$. Following mechanical separation, the mineral composition is analysed by petrographic microscopy supplemented with cathodoluminescence in order to identify binder contamination from aggregates and unburnt limestone (Heinemeier et al., 2010 and references therein). In chemical separation, binder carbonate is gradually dissolved by 
pouring $85 \%$ phosphoric acid over the powder mortar under vacuum (Heinemeier et al., 2010), under the assumption that mortar binder carbonate dissolves much more easily than limestone. However, significant amounts of detrital carbonate and other carbon sources are also dissolved, therefore precluding the determination of the correct age.

In addition, mechanical methods involving manual disaggregation have been used as an alternative to the wet chemical method for mortars with calcareous aggregates (Cimitan et al., 1991; Casadio et al., 2005; Nawrocka et al., 2005; Ortega et al., 2008). Mechanical binder separation is recommended when carbonate contamination has been observed during petrographic analysis.

An effective separation method of very pure binder fraction to assess radiocarbon dating is proposed in the present contribution. The elimination of contaminant error sources and the suitable selection of mortar samples enable the reliable dating. Petrographic analysis under polarizing light microscopy is used to identify different mineralogical phases of mortar samples, aggregate nature, and the limestone fragment remains. It also provides the identification of possible features of mortar degradation (organic and inorganic) and, therefore, allows the selection of a suitable sample for radiocarbon dating. To obtain datable binder, thin-section assessment is essential and offers one of the most effective methods for mortar sampling. A more detailed microscopic analysis can be provided by Scanning Electron Microscopy, which allows contaminant error sources of the mortar sample on a small scale to be identified.

Once the aggregate nature and the occurrence of other carbonate materials are established, the binder carbonates are separated by a combined mechanical and physical procedure (Ortega et al., 2008). This method removes the carbonate fraction, lime lumps and the charcoal particles. The extraction procedure allows to obtain binder reliable for dating without using partial acid digestion and several radiocarbon measurements of complex interpretation. In order to test the effectiveness of mechanical separation and to verify the purity of the binder, Scanning Electron Microscope (SEM), X-ray diffraction (XRD) analyses and thermogravimetric analysis (TGA) were performed. To test the developed procedure, historic lime mortars from the parish church of Santa Maria la Real (Zarautz, northern Spain) have been ${ }^{14} \mathrm{C}$ dated.

\section{Materials and methods}

The mortars were thoroughly examined in the laboratory using a stereo-zoom microscope and carefully disaggregated to avoid breaking the existing aggregates.

Thin sections and polished sections of the mortars were prepared in an impregnation unit under vacuum with an epoxy resin. These were polished with $15 \mu \mathrm{m} \mathrm{Al}_{2} \mathrm{O}_{3}$ abrasive and the final lapping was performed with diamond pastes $(15-1 \mu \mathrm{m})$. Thin-sections were analysed by light polarized microscopy using a petrographic polarizing Olympus $\mathrm{BH} 2$ microscope equipped with an Olympus DP-10 digital camera. Scanning electron microscopy observations were performed with a JEOL JSM-7000F Schottky-type field emission scanning electron microscope operating with an Oxford Pentafet photon energy instruments Link Isis X-ray (EDX) microanalysis system. Samples were carbon-coated to eliminate charging effects. The cathodoluminescence (CL) study was performed using a 
Technosyn Cold Cathode Luminescence system, model 8200 Mk II, mounted on an Olympus trinocular research microscope with a maximum magnification capability of 400 $x$, using universal stage objectives. Standard operating conditions included an accelerating potential of $12 \mathrm{kV}$ and $0.5-0.6 \mathrm{~mA}$ beam current with a beam diameter of approximately $5 \mathrm{~mm}$. X-ray diffraction (XRD) was carried out using monochromatic $\mathrm{Cu}$ $\mathrm{k}_{\alpha 1} \mathrm{X}$-radiation at $40 \mathrm{kV}$ and $20 \mathrm{~mA}$, speed of $0.05 \%$ and $2 \theta$ ranging from 3 to 74 from a Philips PW1710 diffractometer.

Thermogravimetric and differential thermal analysis were also performed in a TA SDT 2960 TG-DSC simultaneous instrument. Pt crucibles containing 5-7 mg of sample were heated at $2^{\circ} \mathrm{C} / \mathrm{min}$ from room temperature to $1000{ }^{\circ} \mathrm{C}$ under dry oxidizing atmosphere. In order to verify the effectiveness of the separation method, several fractions during extraction process have been analyzed by above described techniques.
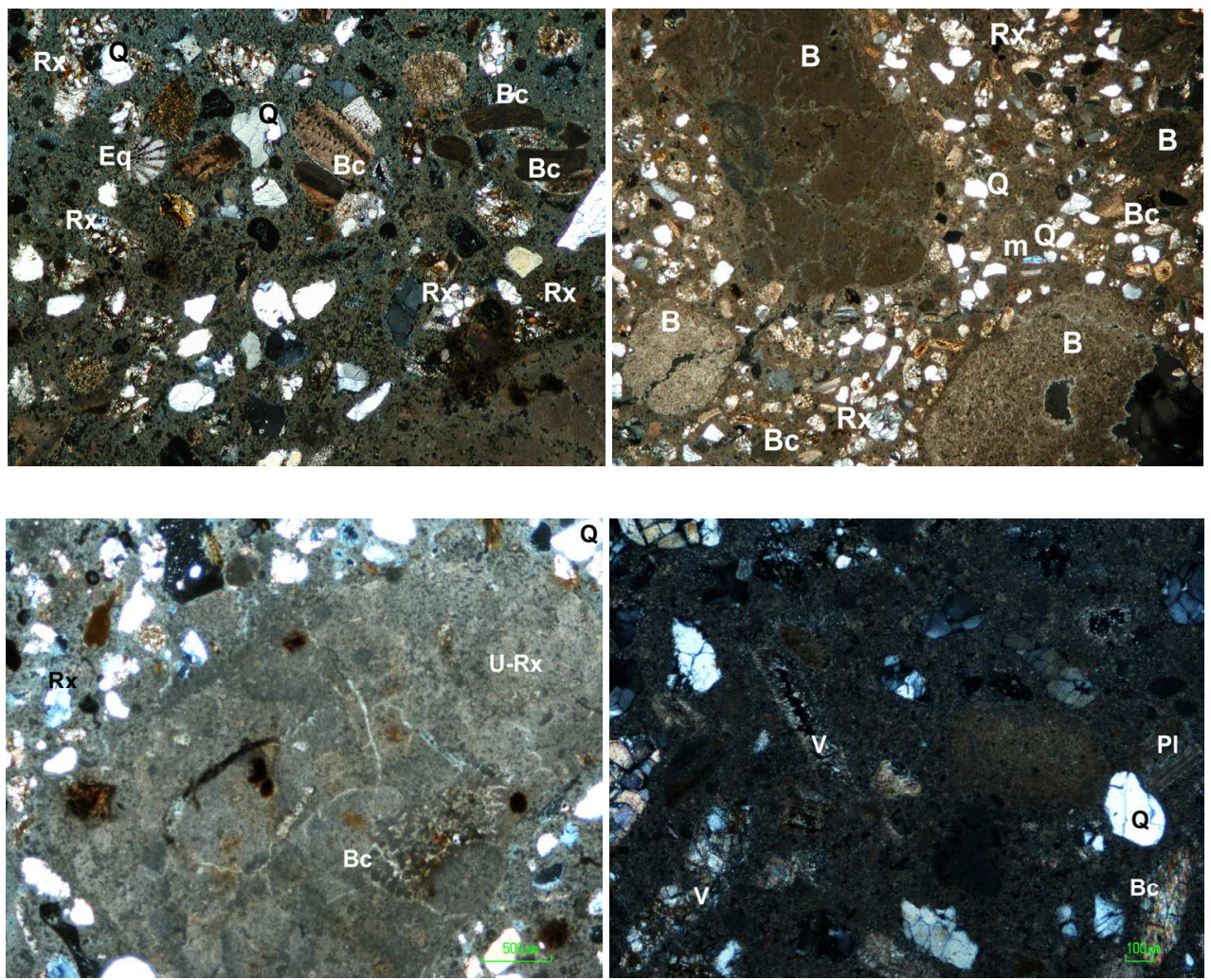

Fig. 1. Photomicrographs of historic lime-mortars. A. Binder with rounded quartz (Q), sandstones (Rx) and biogenic carbonate fragments (Bc: bioclasts, Eq: echinoderm).

B. Carbonate "pure binder" globules (B) with fractures. Rx: rock fragments, m: muscovite, Q: quartz, Bc: bioclasts . C. Fossils inside of an unburned limestone fragment (U-Rx).

Bc: bioclasts, Rx: rock fragments, Q: quartz. D. Void (V) filled with secondary carbonate. Q: quartz, Bc: bioclasts, Pl: plagioclase. 
Before sample preparation for dating, the mortar samples were subjected to petrographic analyses in order to determine binder and aggregate types. Thin-section analysis shows that beach sand aggregates were used as a mortar mixture in all samples. Rounded detrital quartz fine grains, carbonate shell fragments, mainly briozooa and ostracods (Fig. 1A) are common. Inorganic detrital carbonate fragments (micritic and sparitic limestone) has been hardly observed (Ortega et al., 2008). Pure carbonate globules, visible at a macroscopic and microscopic scale, are common (Fig. 1B). In previous works, these globules have been explained as not complete homogeneous mixture of lime binder and aggregates featured by the presence of retraction fractures (Nawrocka et al., 2005). However in this study, most of the globules constitute an incomplete burned limestone as suggest the occurrence of fossil fragments within these globules (Fig. 1C). The petrographic study also reveals the occurrence of voids and fractures in the mortars refilled with secondary carbonate (Fig. 1D).

Once established the mortar nature and determinate the grade of alteration cathodoluminescence analyses was performed over mortar thin section. This method is very useful complement to petrographic microscopy and is especially sensitive when it comes to distinguishing between carbonate phases with slightly different crystallinity and trace element chemistry (Marshall, 1988; Machel, 2000; Pagel, 2000). Natural calcites and dolomites in sedimentary rocks show luminescence in different colours and intensities revealing complex history of cements and crystal growth history (Marshall, 1988). The causes of the luminescence are defects in the crystal structure or impurities hosted in the crystal lattice. The cathodoluminescence of carbonates is mostly due to the presence of transitional elements and, in particular, to $\mathrm{Mn}^{2+}$ as a main activator ion (orange luminescence); $\mathrm{Fe}^{2+}$ is believed to be the most important quencher ion (Marshall, 1988; Corazza et al., 2001). The most important factor determining the colour and intensity of the luminescence is the $\mathrm{Mn}^{2+} / \mathrm{Fe}^{2+}$ ratio in the calcite (Habermann et al., 2000). The chemical activity of these ions is controlled by the decreasing $\mathrm{pH}$ in crystallizing calcite. So, is possible to assess how many carbonate contaminants are in the mortars by performing image analyses, but the results are at best only semi-quantitative due to many problems (Lindroos et al., 2007).
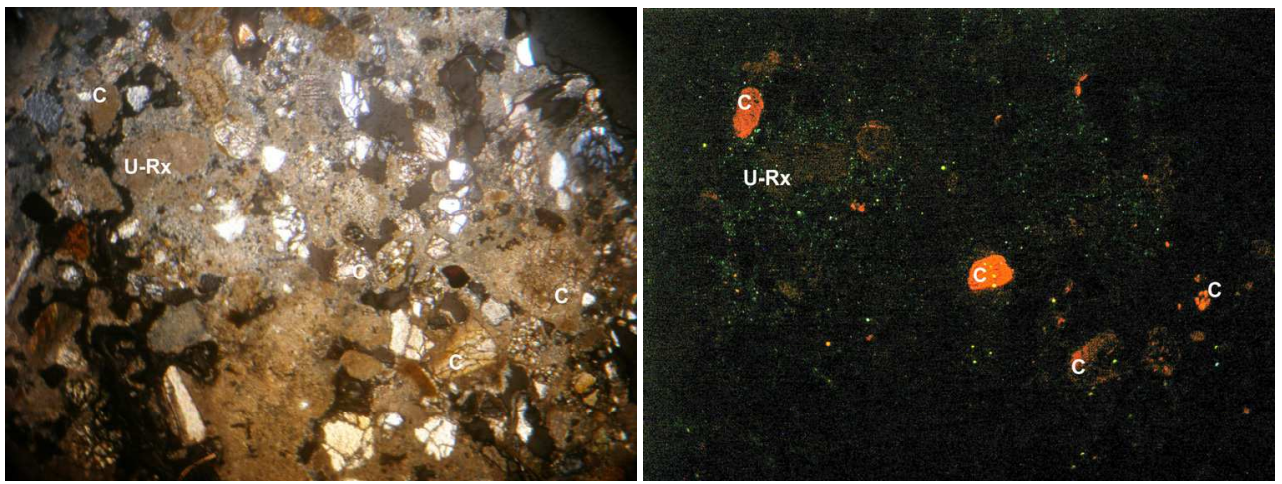

Fig. 2. Photomicrographs of historic lime-mortars. A. Unburned limestone (U-Rx) remains and sparite limestone detrital grains (C). B. Cathodoluminescence image. 
The binder phase is typically a spongy network of microscopic crystal of calcite enclosing the aggregate particles as reveals the SEM study. During mortar cementation, the expelled water generates porosity and at the same time transports dissolved atmospheric $\mathrm{CO}_{2}$ to crystallize $\mathrm{CaCO}_{3}$. In cathodoluminescence, the binder is usually dark brown or nearly black (Fig. 2B) revealing a rapid hardening process in contact with atmospheric oxygen. This very oxidizing conditions leads to the precipitation of both $\mathrm{Mn}$ and Fe as oxides and hydroxides, and therefore preclude the diffusion of activator elements in the calcite lattice.

Grains with well-developed bright yellowish to red luminescence reveal the occurrence of carbonates with diagenetic modification and correspond to fragments of different inherited carbonate types included in the aggregates. The dully-luminescent grains correspond to residues of unburned limestone (Fig. 2).

\section{Extraction procedure}

The protocol established to obtain pure datable binder is based on a modification of the procedure described by Sonninen and Jungner (2001) and largely used in the radiocarbon dating of mortar (Nawrocka et al., 2005; Lindroos et al., 2007; Nawrocka et al., 2007; Goslar et al., 2009; Nawrocka et al., 2009; Heinemeier et al., 2010). The mortar samples were gently crumbled up manually or with a mortar and, based on the assumption that binder carbonates are characterized by an easily breakable aggregation structure, they were disaggregated by means of an ultrasonic bath.

This method is based on the fact that particle size is related to mechanical or chemical origin. Particles of mechanical origin always have a grain size of over $1 \mu \mathrm{m}$, whereas chemical reactions produce colloids that flocculate and regrow, generating finer particles. This process has been demonstrated for subaerial media (Wilson \& Spengler, 1996) and for aqueous media (Davis \& Kent, 1990; Salama \& Ian, 2000). Therefore, this work has optimized a procedure to obtain particles of under $300 \mathrm{~nm}$, which ensures that all the carbonate separated has been generated by slaked lime carbonation, and consequently that the carbon measured corresponds to atmospheric carbon.

The methodology is a variation on the particle-fractionation techniques routinely used in soil mineralogy studies. Sedimentation and centrifugation allow the routine separation of particles of $<2 \mu \mathrm{m}$ (Laird \& Dowdy, 1994; Soukup et al., 2008). Particle fractionation is based on the differential settling of the particles in a liquid so that centrifugation increases the rate of sedimentation, accelerating the process. The relation between the sedimentation rate and particle size is given in Stoke's Law (Stokes, 1851):

$$
\mathrm{V}=\mathrm{g}\left(\mathrm{s}_{\mathrm{p}}-\mathrm{s}_{\mathrm{l}}\right) \mathrm{D}^{2} / 1.8 \mathrm{~h}
$$

where $\mathrm{V}$ is the particle velocity $(\mathrm{cm} / \mathrm{s})$ in the liquid of density $\left(\mathrm{s}_{\mathrm{l}}\right)$; $\mathrm{g}$ is gravity acceleration $\left(9.8 \mathrm{~cm} / \mathrm{s}^{2}\right) ; \mathrm{s}_{\mathrm{p}}$ is the particle density $\left(\mathrm{g} / \mathrm{cm}^{3}\right) ; \mathrm{D}$ is the equivalent spherical diameter of the particle (cm); and $\mathrm{h}$ is the viscosity of the liquid (Pa.s).

The main goal of this separation procedure is to avoid (or minimize) the aggregation of small particles and to fractionate particles of under $1 \mu \mathrm{m}$. To explain this extraction method, the procedure has been designed in different particle-fractionation steps. (i) The manually crumbled mortar is placed in an ultrasonic bath of ultrapure water for 10 minutes to promote further crumbling. Afterwards, the suspended fraction is extracted. (ii) This 
fraction is purified through centrifugation at $3000 \mathrm{rpm}$ for 10 minutes using a Kubota 3000 centrifuge (Kubota Corporation, Tokyo, Japan). (iii) Then, the topmost $50 \mathrm{ml}$ by volume is collected, corresponding to the under $20 \mu \mathrm{m}$ fraction. In order to assess the particle size obtained, a Mastersizer 2000 particle analyser (Malvern Instruments Ltd, Malvern, UK) was used to measure grain size. Figure $3 \mathrm{~A}$ gives a particle-distribution histogram with two modes, one for fine particle size $(0.2 \mu \mathrm{m})$ and the other for coarse $(\approx 1.5 \mu \mathrm{m})$, with a tail reaching $20 \mu \mathrm{m}$. (iv) In order to improve the grain-size separation of this $<20 \mu \mathrm{m}$ fraction, it is resuspended in an aqueous medium at a $\mathrm{pH} \approx 8$ and then placed in the ultrasonic bath to promote crumbling. The $\mathrm{pH} \approx 8$ aqueous medium favours optimal scattering of small crystals (Warkentin \& Maeda, 1980). This suspension is centrifuged for one minute at 1000 rpm, after which the topmost $15 \mathrm{ml}$ are collected, which corresponds to a grain-size fraction of less than $1 \mu \mathrm{m}$ and a mode of $200 \mathrm{~nm}$ (Fig. 3B and Fig. 5). The XRD tests are performed to ensure that the extraction method was effective for lime-binder refining. The final fractions thus obtained were composed only by calcite (Fig. 4A) whereas previous fractions from the step (iii) content some residual aggregates of clay minerals and quartz nature (Fig. 4B). This procedure is repeated as necessary to obtain a sufficient amount for AMS analysis. In this study, this process had to be repeated five to eight times to obtain 40 to $80 \mathrm{mg}$.

This method separates the carbonate binder particles (formed through the reaction of the lime with atmospheric carbon) from the detrital and/or fragmented particles corresponding to aggregates and unburned limestone. Therefore, this extraction procedure eliminates any supply of dead or non-atmospheric carbon. The separation of the carbonate binder has been confirmed by SEM microscopy observations. The figure 5A shows planar carbonate grains of the binder with a grain size of approximately $0.2 \mu \mathrm{m}$ in the useful fraction after step (iv). The coarse fraction discarded can be observed in figure 5B. This fraction commonly contains particles with a grain size of over $1 \mu \mathrm{m}$ and habits suggesting an inherited origin of the carbonate.

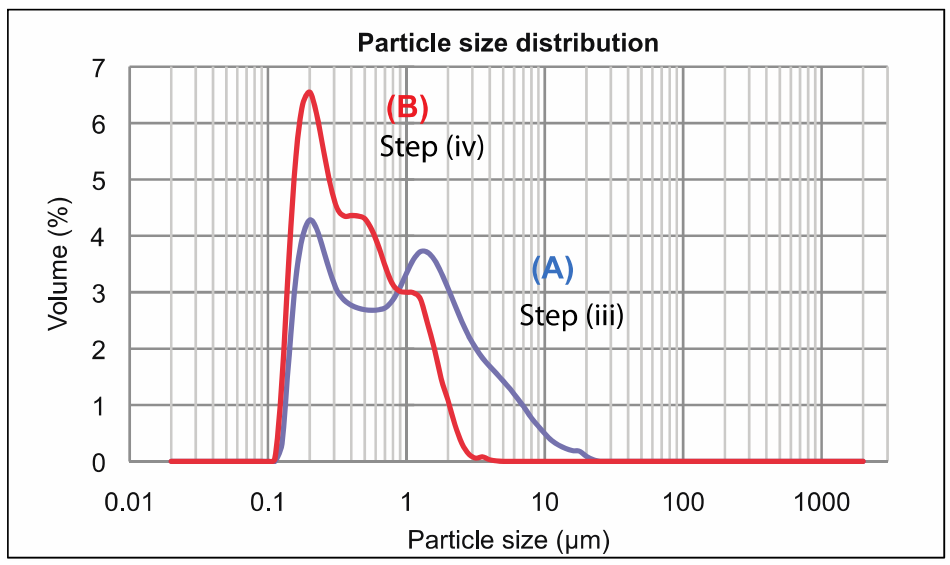

Fig. 3. Grain-size histograms of particles extracted from roman mortar (sample SNR-579). A. The distribution after extraction step (iii) exhibits bimodality with a large number of particles in a mode at small sizes $(0.2 \mu \mathrm{m})$ and coarse size mode $(\approx 1.5 \mu \mathrm{m})$ and with a tail reaching to $20 \mu \mathrm{m}$. B. The distribution after extraction step (iv) shows a mode at $0.2 \mu \mathrm{m}$ and to shoulder at $0.5 \mu \mathrm{m}$ and $1 \mu \mathrm{m}$ with a little tail reaching to $4 \mu \mathrm{m}$. 


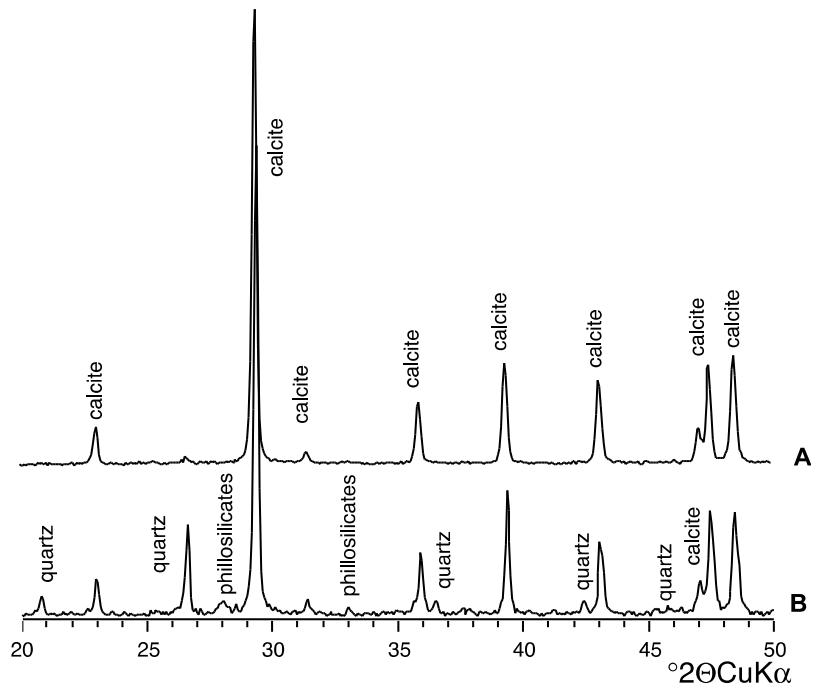

Fig. 4. XRD patterns of binder mortar. A. After extraction step (iv). B. The "coarse fraction" after extraction steep (iii).
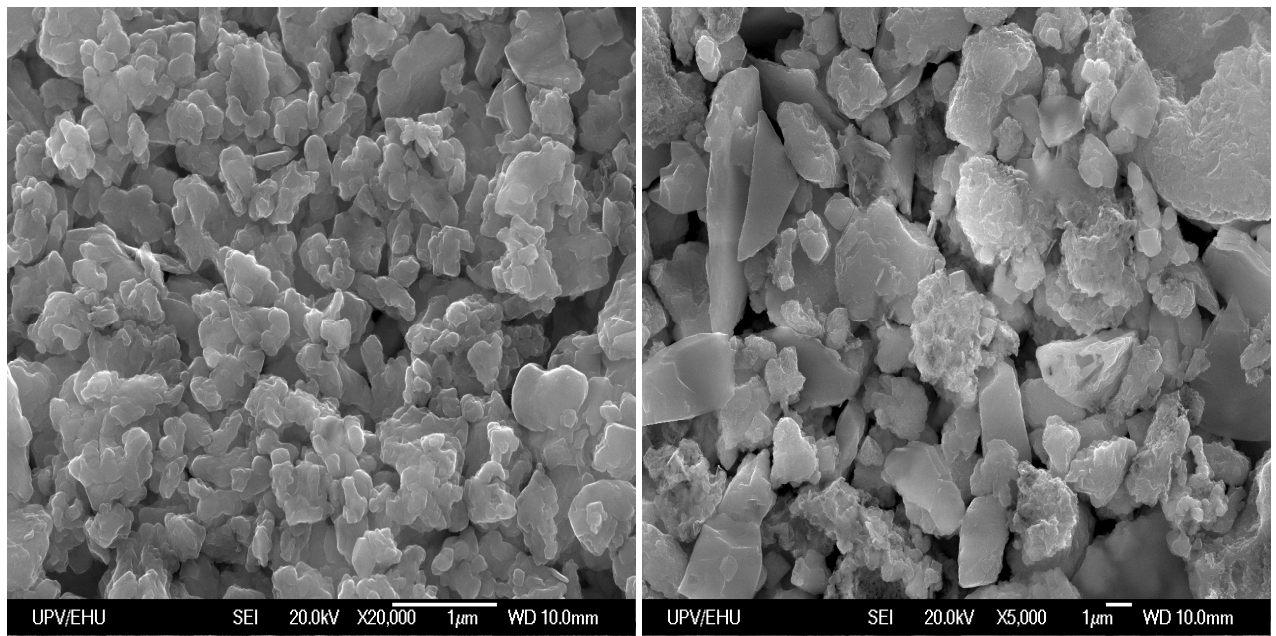

Fig. 5. SEM photomicrographs of extracted carbonate from SNR-108 mortar sample. A. Fine fraction with average particle size ca $0.2 \mathrm{~nm}$. B. Larger fraction with detrital or mechanically fragmented inherited carbonates.

Moreover, thermogravimetric analysis and differential thermal analysis (DT-TGA) has been carried out to obtain a complementary knowledge about the binder composition and purity. The figure 6 illustrates representative thermograms obtained for studied samples. The thermograms of all samples are typical of aerial lime mortars of carbonate nature with a typical weight loss at temperatures ranging from 600 to $750{ }^{\circ} \mathrm{C}$ (Bakolas et al., 1998; Marques et al., 2006; Adriano et al., 2009). 


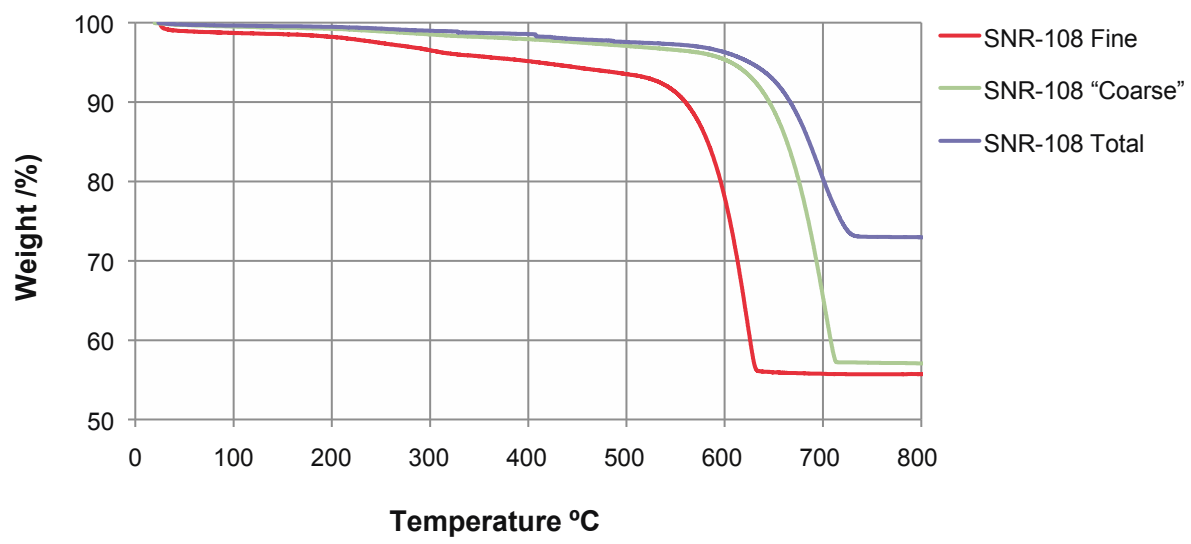

Fig. 6. Thermal analysis curves of mortar and different binder fractions of SNR-108 sample.

The finer grain size fraction corresponding to pure binder reacts at lower temperatures than the coarse size fraction and bulk mortar, showing the shifting of weigth loss temperature from ca $700{ }^{\circ} \mathrm{C}$ to $600{ }^{\circ} \mathrm{C}$ as purity increases and grain size decreases. The continuous weight loss observed between $200^{\circ} \mathrm{C}$ and $550{ }^{\circ} \mathrm{C}$ in the lime fine fraction could be attributed to $\mathrm{Ca}(\mathrm{OH})_{2}$ dehydration (Paama et al., 1998).

The shifting of temperatures reveals that this fine fraction corresponds to the most reactive fractions of the sequential solutions performed by other researchers (Sonninen \& Jungner, 2001; Lindroos et al., 2007; Nawrocka et al., 2009; Heinemeier et al., 2010). The main advantage of this extraction method consists in the removal of any inherited carbonate contamination.

To test the effectiveness of the developed extraction method, five mortar samples were selected for radiometric dating corresponding to different periods ranging from Roman (1st to 4 th centuries AD) to Medieval (9th to 14th centuries).

\section{Results and discussion}

Santa Maria la Real is located within and surrounding the parish church of the Zarautz town (northern Spain). The town is located on the Gulf of Biscay, in front of a sandy beach two kilometres long. Excavations of the interior of the church of Santa Maria la Real have identified successive periods of occupation since the Iron Age (Ibáñez Etxeberria, 2003; Ibáñez Etxeberria \& Moraza, 2005; Ibañez Etxeberria, 2009) (Fig. 7). Remains from the Iron Age and a long-term stable Roman establishment (between the 1st to 5th centuries AD) were located in the room structure uncovered. Within the Roman zone, several room units have been discovered. A new reoccupation of the space by different human groups took place starting in the late 9 th century or early 10 th century.

Radiocarbon dating of the lime mortars has revealed the age of various construction phases at the temple of Santa Maria la Real (Table 1). The earliest age determined ranges between 90 - 210 AD (with a 95.4\% probability) and corresponds to construction phases at the end of the 1st or 2nd centuries of the present era (Fig. 9). This age is in agreement with the relative 
timeline indicated by the abundance of common Early Empire Roman pottery and with the remains of Hispanic terra sigillata pottery found at the site (Ceberio, 2009; Cepeda Ocampo, 2009; Esteban Delgado et al., in press). The oldest remains of Hispanic terra sigillata pottery correspond to pottery produced at Tritium magallum from $40 \mathrm{AD}$ to $60 \mathrm{AD}$, equivalent to the earliest age of foundations for the Roman structures. In fact, the fill of a foundation trench for the main structure preserved from the Roman period contained fragments of Hispanic terra sigillata pottery (Cepeda Ocampo, 2009) and of common hand-made pottery (Ceberio, 2009), as well as a carbon fragment in the mortar. This carbon fragment was dated by ${ }^{14} \mathrm{C}$ at $1930 \pm 40$ (Ua-20919), corresponding to a calibrated age of $40 \mathrm{BC}$ to $140 \mathrm{AD}$ with a $95.4 \%$ probability (Ibañez Etxeberria \& Sarasola Etxegoien, 2009). These ages are perfectly consistent since in ${ }^{14} \mathrm{C}$ dating calibration, one has to take into account the problem of old wood (Bowman, 1990). Wood or carbon fragments in a mortar are always older than the mortar itself. The difference can be significant if the carbon analysed derives from the internal part of the tree trunk used as fuel to produce the mortar, or even more so if the wood comes from trees cut long before.

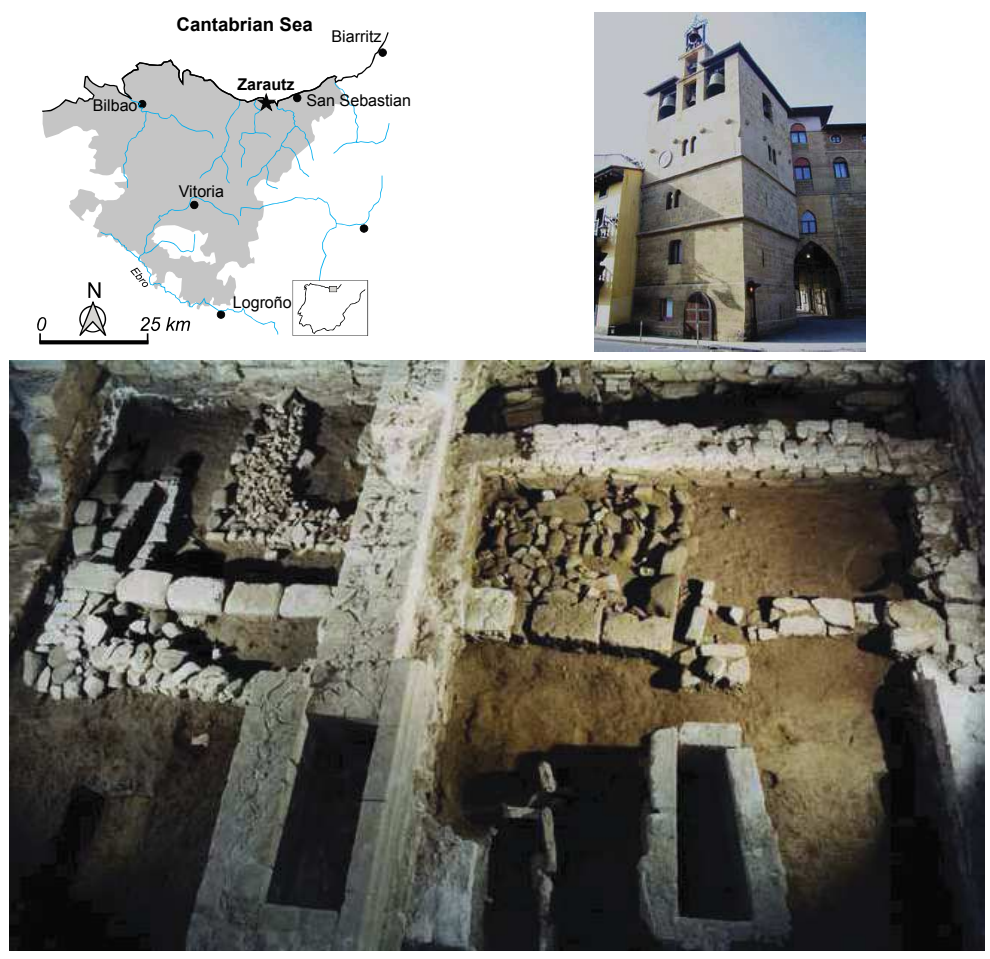

Fig. 7. Geographical location of the church of Santa Maria la Real and one temple view.

The evolution of the site is attested through the layout of four religious temples and an associated necropolis (Fig. 8). Overall, this confirms the foundation and the uninterrupted development of the present-day community of Zarautz from the early and late Medieval periods until the existence of the present temple. 


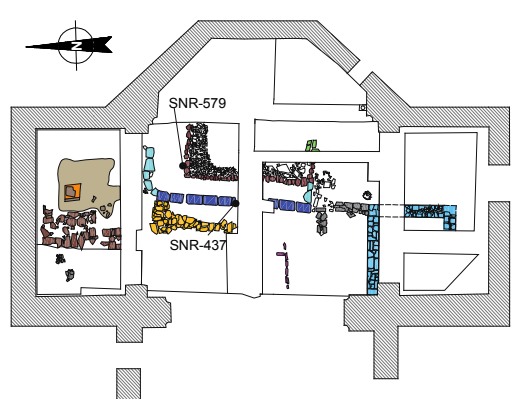

Roman Epoch level

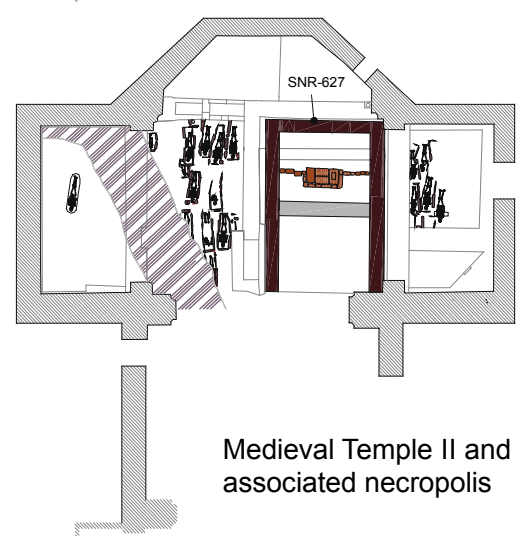



Medieval Temple I and associated necropolis

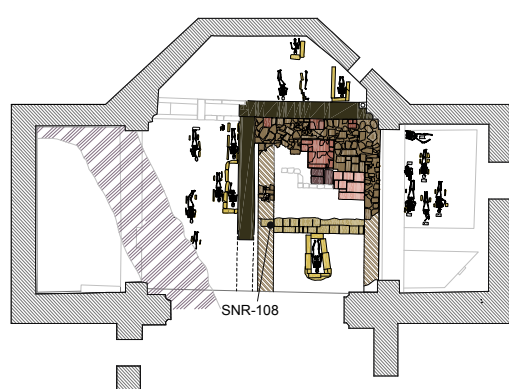

Medieval Temple III and associated necropolis

Fig. 8. Scheme of the studied temples and the location of mortar samples.

\begin{tabular}{|c|c|c|c|c|c|c|}
\hline Lab Code & Sample & $\begin{array}{c}\text { Conventional } \\
\text { Age }\end{array}$ & $\delta^{13} \mathrm{C}$ & \multicolumn{2}{|c|}{ Calibrated Age } & \multirow{2}{*}{$\begin{array}{c}\text { Archaeological } \\
\text { Age }\end{array}$} \\
\cline { 5 - 7 } & & & & $68.20 \%$ & $95.40 \%$ & Roman \\
\hline Beta-300900 & SNR-579 & $1860+/-30 \mathrm{BP}$ & $-9.4 \%$ & $90-214 \mathrm{AD}$ & $80-231 \mathrm{AD}$ & Ro \\
\hline Beta-300899 & SNR-437 & $1870+/-30 \mathrm{BP}$ & $-10.5 \%$ & $92-210 \mathrm{AD}$ & $73-227 \mathrm{AD}$ & Roman \\
\hline Beta-300898 & SNR-190 & $1220+/-30 \mathrm{BP}$ & $-17.3 \%$ & $729-870 \mathrm{AD}$ & $692-888 \mathrm{AD}$ & Temple I \\
\hline Beta-300901 & SNR-627 & $1100+/-30 \mathrm{BP}$ & $-17.4 \%$ & $897-985 \mathrm{AD}$ & $887-1014 \mathrm{AD}$ & Temple II \\
\hline Beta-300897 & SNR-108 & $1060+/-30 \mathrm{BP}$ & $-11.8 \%$ & $905-1019 \mathrm{AD}$ & $\begin{array}{l}896(16.2 \%) \\
920 \mathrm{AD}\end{array}$ & Temple III \\
& & & & & $(79.2 \%) 1024 \mathrm{AD}$ & \\
\hline
\end{tabular}

Table 1. AMS ${ }^{14} \mathrm{C}$ dates for mortar samples of Santa Maria la Real obtained with OxCal v 4.1 (Bronk Ramsey, 2009) and IntCal09 atmospheric data (Reimer et al., 2009).

This date belongs to the earliest years of Roman occupation on the northern coast of Spain, related with the creation of coastal sites for maritime trade, which took place especially starting in the second half of the 1st century AD (Fernández Ochoa \& Morillo Cerdán, 1994; Esteban Delgado, 2004). In contrast, despite the persistence of this settlement for various centuries during the Roman period, as shown by the finding of Late Empire coins and 
common pottery (3rd-5th centuries) (Cepeda Ocampo, 2009; Esteban Delgado et al., in press), no significant later structures have been dated. The main reason is that, at this site, the later buildings documented are of poorer construction, with walls mortared with mud (Ibañez Etxeberria, 2009).



Fig. 9. Calibration of ${ }^{14} \mathrm{C}$ dates of the Santa Maria la Real mortar samples, obtained with OxCal v 4.1 (Bronk Ramsey, 2009) and IntCal09 atmospheric data (Reimer et al., 2009).

For the Medieval period, the dates obtained correspond to the construction of the perimeter walls for various buildings of the parish church. These buildings are built one atop the other on the same religious site (Fig. 8) due to greater need for space as a result of the population growth of Zarautz in the Early Medieval period. The oldest age, consistent with the archaeological findings, is provided by the mortar in wall SNR-190 (Temple I), with a probable age of $772 \mathrm{AD}$ to $870 \mathrm{AD}(68.2 \%$ confidence interval) (Fig. 9). This dating is close to that established by archaeological analyses for an arch of the Temple I, and therefore is not likely a spurious aged dating. Slightly older ages were obtained in skeletons from burials associated with Temple I. Thus, skeleton sample Ua-16897 provides an imprecise age of 558 $\mathrm{AD}$ to $870 \mathrm{AD}$ (95\% confidence interval), and probably prior to $770 \mathrm{AD}(68.2 \%)$ (Ibañez Etxeberria \& Sarasola Etxegoien, 2009).

The other two ages belong to the perimeter walls of Temples II and III. The age for Temple II must be prior to 985 AD (68.2\%), whereas Temple III provides an age of 970 AD to 1020 AD $(95 \%)$. These two construction phases give ages very close to each other, which is consistent with the population surge at the end of the turn of the millennium and the subsequent need for a larger temple.

The ages determined are coherent not only with the archaeological information, but also with previous radiometric dating (Fig. 10). The age for Temple II is very close to those determined for the burials in stone-slab graves in the necropolis, with a dating of $890 \mathrm{AD}$ to $1040 \mathrm{AD}$ (68\% confidence interval), whereas individuals associated with the Temple III necropolis, with walled graves, give ages of 990 AD to 1160 AD (Ibáñez Etxeberria, 2003). 


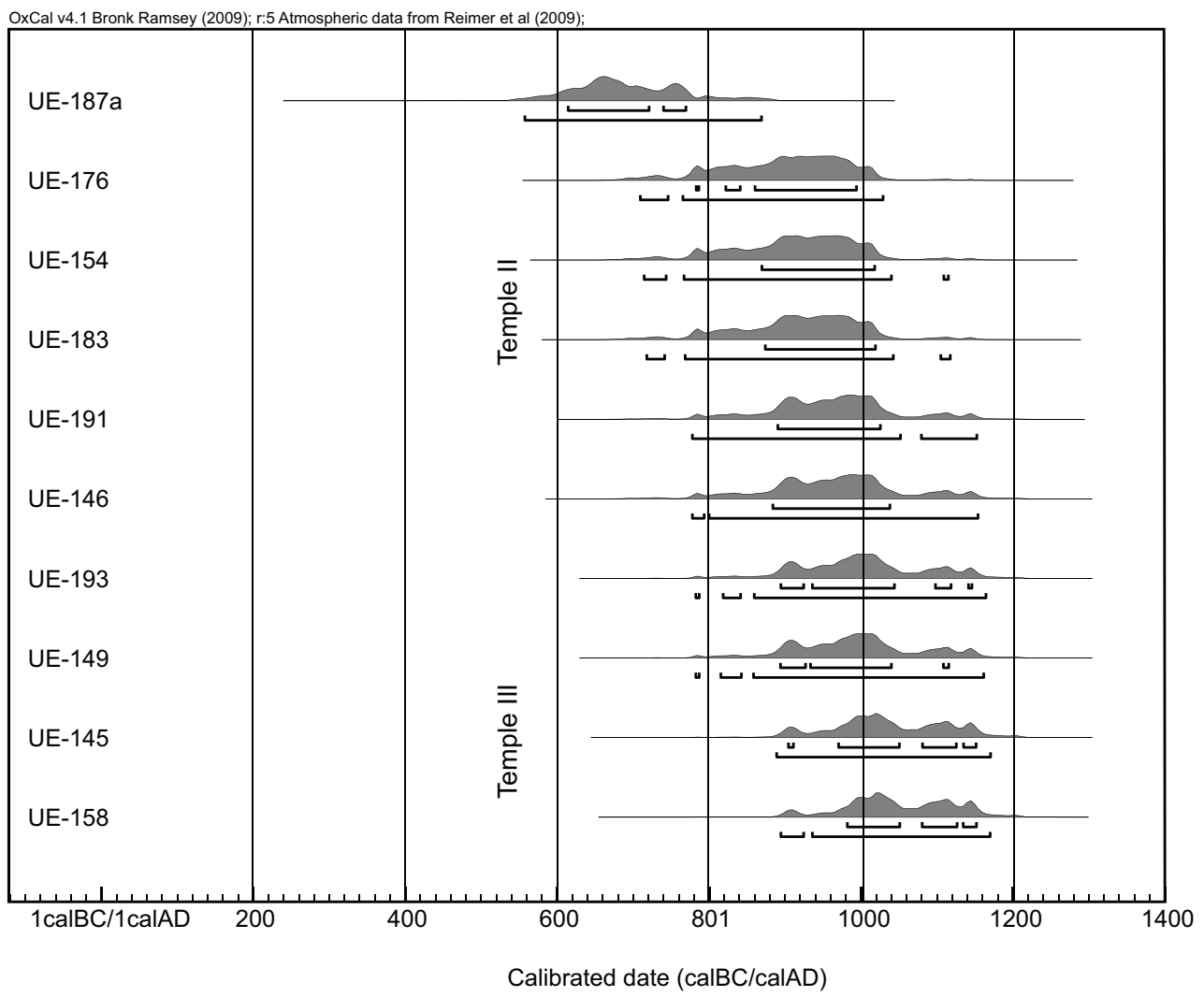

Fig. 10. Calibration of ${ }^{14} \mathrm{C}$ dates of individuals from the necropolis associated to the Santa María la Real, obtained with OxCal v 4.1 (Bronk Ramsey, 2009) and IntCal09 atmospheric data (Reimer et al., 2009).

\section{Conclusions}

Lime mortar radiocarbon dating will result ambiguous because of $\mathrm{CO}_{2}$ contamination from inherited carbonates and, burial and/or weathering modifications. Therefore, an effective extraction method of binder is necessary in order to prevent the determination of older or younger ages.

A new combined mechanical and physical procedure was established to obtain very pure binder fraction. The extraction of particles of less than $1 \mu \mathrm{m}$ in size was developed allowing to achieve suitable material for lime mortar dating. This extraction method eliminates the sources of contamination in carbon, fundamental issue for radiometric dating of lime mortars. Thus, this procedure removes partial acid digestion from dating procedure of binder and several radiocarbon measurements of complex interpretation. The obtained pure binder after separation procedure is enough in quantity and quality for radiocarbon dating. The adequate binder carbonate selection has a broad application on establishing the chronology of the different construction phases of buildings. 
For the selection of a suitable sample for radiocarbon dating, petrographic analysis is essential. The identification of different mineralogical phases of mortar samples, aggregate nature, and the limestone fragment remains as well as the recognition of possible features of mortar degradation (organic and inorganic) are issues to elucidate. Moreover, analysis performed by Scanning Electron Microscopy allows to identify contaminant error sources of the mortar sample on a small scale.

The effectiveness of mechanical separation and the verification of binder purity have been proved by X-ray diffraction, Scanning Electron Microscope analyses and thermogravimetric analysis and differential thermal analysis.

The preparation method was successfully applied to distinctive physical characteristic bearing and varying age five mortars. Mortars correspond to perimetric walls of different age buildings of the Santa María la Real church in Zarautz. Moreover, the elimination of the source of error in inherited carbon provides ages that are relatively insensitive to aging when determining the dates of these historic buildings and of their construction phases.

The radiometric ages of studied mortars are consistent with the established by archaeological and historical studies for different construction phases of the studied church. Therefore, the procedure of sample preparation considerably simplifies the performance of radiometric measurements and their interpretation.

\section{Acknowledgments}

This paper has received financial support from the project IT-315-10 of the Basque Government and UNESCO 09/01 and EHU10/32 projects of The University of the Basque Country. We thank Christine Laurin, who has greatly improved the English text.

\section{References}

Adriano, P., Silva, A. S., Veiga, R., Mirao, J. \& Candeias, A. E. (2009). Microscopic characterisation of old mortars from the Santa Maria Church in Evora, Materials Characterization, Vol. 60, No. 7, pp. 610-620, ISSN 1044-5803

Al-Bashaireh, K. \& Hodgins, G. W. L. (2011). AMS 14C dating of organic inclusions of plaster and mortar from different structures at Petra-Jordan, Journal of Archaeological Science, Vol. 38, No. 3, pp. 485-491, ISSN 0305-4403

Ambers, J. (1987). Stable carbon isotope ratios and their relevance to the determination of accurate radiocarbon-dates for lime mortars, Journal of Archaeological Science, Vol. 14, No. 6, pp. 569-576, ISSN 0305-4403

Bakolas, A., Biscontin, G., Moropoulou, A. \& Zendri, E. (1998). Characterization of structural byzantine mortars by thermogravimetric analysis, Thermochimica Acta, Vol. 321, No. 12, pp. 151-160, ISSN 0040-6031

Ball, R. J., El-Turki, A. \& Allen, G. C. (2011). Influence of carbonation on the load dependent deformation of hydraulic lime mortars, Materials Science and Engineering: A, Vol. 528, No. 7-8, pp. 3193-3199, ISSN 0921-5093

Baxter, M. S. \& Walton, A. (1970). Radiocarbon dating of mortars, Nature, Vol. 225, No. 5236, pp. 937-938, ISSN 0028-0836 
Benea, V., Vandenberghe, D., Timar, A., Van den Haute, P., Cosma, C., Gligor, M. \& Florescu, C. (2007). Luminescence dating of Neolithic ceramics from Lumea Noua, Romania, Geochronometria, Vol. 28, pp. 9-16, ISSN 1733-8387

Berger, R. (1992). C-14 dating mortar in Ireland, Radiocarbon, Vol. 34, No. 3, pp. 880-889, ISSN 0033-8222

Bowman, S., (1990). Radiocarbon dating, University of California Press ISBN 0520070372, Berkeley

Bronk Ramsey, C. (2009). Bayesian analysis of radiocarbon dates, Radiocarbon, Vol. 51, No. 1, pp. 337-360, ISSN 0033-8222

Casadio, F., Chiari, G. \& Simon, S. (2005). Evaluation of binder/aggregate ratios in archaeological lime mortars with carbonate aggregate: A comparative assessment of chemical, mechanical and microscopic approaches, Archaeometry, Vol. 47, pp. 671-689, ISSN 0003-813X

Ceberio, M., (2009). La cerámica común no torneada de época romana del yacimiento de Santa María la Real de Zarautz (País Vasco). Una aproximación a su caracterización tipológica, in Santa María La Real de Zarautz (País Vasco) continuidad y discontinuidad en la ocupación de la costa vasca entre los siglos $V$ a. C. y XIV d. C, Ibáñez Etxeberria, Á. (Ed.), pp. 176-190, Sociedad de Ciencias Aranzadi ISBN 978-84-931930-9-6, Donostia

Cepeda Ocampo, J. J., (2009). Hallazgos romanos en Santa María la Real de Zarautz (País Vasco). La terra sigilata, las lucernas y monedas, in Santa María La Real de Zarautz (País Vasco) continuidad y discontinuidad en la ocupación de la costa vasca entre los siglos $V$ a. C. y XIV d. C, Ibáñez Etxeberria, Á. (Ed.), pp. 258-272, Sociedad de Ciencias Aranzadi ISBN 978-84-931930-9-6, Donostia

Cimitan, L., P., R. \& Zaninetti, A. (1991). Studio delle tecniche di disgregazione per le indagini diagnostiche delle malte. Materiali e Strutture, Problemi di Conservazione, Vol. 3, pp. 121-130, ISSN 1121-2373

Corazza, M., Pratesi, G., Cipriani, C., Lo Guidice, A., Rossi, P., Vittone, E., Manfredotti, C., Pecchioni, E., Manganelli del Fa, C. \& Fratini, F. (2001). Ionoluminescence and cathodoluminescence in marbles of historic and architectural interest, Archaeometry, Vol. 43, pp. 439-446, ISSN 0003-813X

Davis, J. A. \& Kent, D. B., (1990). Surface complexation modeling in aqueous geochemistry, in Mineral-Water Interface Geochemistry, Hochella, M.F. \& White, A.F. (Eds.), pp. 177260, Mineralogical Society of America ISBN 0-939950-28-6,

Esteban Delgado, M. (2004). Tendencia en la creacción de asentamientos durantes los primeros siglos de la era en el espacio litoral guipuzcuano, Kobie, Vol. 6, No. 1, pp. 371-380, ISSN

Esteban Delgado, M., Martínez Salcedo, A., Ortega Cuesta, L. A., Alonso-Olazabal, A., Izquierdo Marculeta, M. T., Rechin, F. \& Zuluaga Ibargallartu, M. C., (in press). Caracterización tecnológica y arqueológica de la cerámica común no torneada de época romana en el País Vasco peninsular y Aquitania meridional: Producción, difusión, funcionalidad, cronología, Eusko Ikaskuntza, Donostia

Fernández Ochoa, C. \& Morillo Cerdán, Á., (1994). De Brigantium a Oiasso : una aproximación al estudio de los enclaves maritimos cantábricos en época romna, Foro Arqueología Proyectos y Publicaciones, ISBN 8460501051, Madrid

Folk, R. L. \& Valastro, S. J. (1976). Successful technique for dating of lime mortar by carbon-14, Journal of Field Archaeology, Vol. 3, pp. 203-208., ISSN 0093-4690

Frumkin, A., Shimron, A. \& Rosenbaum, J. (2003). Radiometric dating of the Siloam Tunnel, Jerusalem, Nature, Vol. 425, No. 6954, pp. 169-171, ISSN 0028-0836

Goedicke, C. (2003). Dating historical calcite mortar by blue OSL: results from known age samples, Radiation Measurements, Vol. 37, No. 4-5, pp. 409-415, ISSN 1350-4487 
Goslar, T., Nawrocka, D. \& Czernik, J. (2009). Foraminiferous limestone in C-14 dating of mortar, Radiocarbon, Vol. 51, No. 3, pp. 987-993, ISSN 0033-8222

Habermann, D., Neuser, R. \& Richter, K., (2000). Quantitative high resolution spectral analysis of $\mathrm{Mn} 2+$ in sedimentary calcite, in Cathodoluminescence in geosciences, Pagel, M. (Ed.), pp. 331-358, Springer ISBN Berlin

Hale, J., Heinemeier, J., Lancaster, L., Lindroos, A. \& Ringbom, Å. (2003). Dating ancient mortar, American Scientist, Vol. 91, pp. 130-137, ISSN 0003-0996

Heinemeier, J., Jungner, H., Lindroos, A., Ringbom, s., von Konow, T. \& Rud, N. (1997a). AMS 14C dating of lime mortar, Nuclear Instruments and Methods in Physics Research Section B: Beam Interactions with Materials and Atoms, Vol. 123, No. 1-4, pp. 487, ISSN 0168-583X

Heinemeier, J., Jungner, H., Lindroos, A., Ringbom, s., von Konow, T., Rud, N. \& Sveinbjornsdottir, A., (1997b). AMS C-14 dating of lime mortar, in Proceedings of the VII Nordic Conference on the Application of Scientific Methods in Archaeology, Edgren, T. (Ed.), pp. 214-215, ISBN 951-9057-27-7,

Heinemeier, J., Ringbom, A., Lindroos, A. \& Sveinbjornsdottir, A. E. (2010). Successful AMS C-14 dating of non-hydraulic lime mortars from the medieval churches of the Aland Islands, Finland, Radiocarbon, Vol. 52, No. 1, pp. 171-204, ISSN 0033-8222

Hiekkanen, M., (1998). Finland's medieval stone churches and their dating - a topical problem., Helsinki, Suomen Museo, p. 143-149.

Ibañez Etxeberria, A., (2009). Santa María la Real de Zarautz (País Vasco): continuidad y discontinuidad en la ocupación de la costa vasca entre los siglos $V$ a.C. y XIV d.C, Sociedad de Ciencias Aranzadi ISBN 978-84-931930-9-6, Donostia

Ibañez Etxeberria, A. \& Sarasola Etxegoien, N., (2009). El yacimiento arqueológico de Santa María de Zarautz (País Vasco), in Santa María la Real de Zarautz (País Vasco): continuidad y discontinuidad en la ocupación de la costa vasca entre los siglos $V$ a.C. y XIV d.C, Ibáñez Etxeberria, Á. (Ed.), pp. 12-84, Sociedad de Ciencias Aranzadi ISBN 97884-931930-9-6, Donostia

Ibáñez Etxeberria, A., (2003). Entre Menosca e Ipuscua: arqueología y territorio en el yacimiento de Santa María La Real de Zarautz (Gipuzkoa), Zarauzko Arte eta Historia Museoa, ISBN 8492303344, Zarautz

Ibáñez Etxeberria, A. \& Moraza, A. (2005). Evolución cronotipológica de las inhumaciones medievales en el Cantábrico Oriental: el caso de Santa María la Real de Zarautz (Gipuzkoa), Munibe, Suplemento, Vol. 57, pp. 419-437, ISSN 1132-2217

Kosednar-Legenstein, B., Dietzel, M., Leis, A. \& Stingl, K. (2008). Stable carbon and oxygen isotope investigation in historical lime mortar and plaster Results from field and experimental study, Applied Geochemistry, Vol. 23, No. 8, pp. 2425, ISSN

Labeyrie, J. \& Delibrias, G. (1964). Dating of old mortar by Carbon-14 method, Nature, Vol. 201, No. 492, pp. 742-743, ISSN 0028-0836

Laird, D. A. \& Dowdy, R. H., (1994). Preconcentration techniques in soil mineralogical analyses, in Quantitative Methods in Soil Mineralogy, Luxmoore, R.J. (Ed.), pp. 236266, Soil Science Society of America ISBN 0-89118-806-1, Madison,WI

Lanas, J., Sirera, R. \& Alvarez, J. I. (2005). Compositional changes in lime-based mortars exposed to different environments, Thermochimica Acta, Vol. 429, No. 2, pp. 219-226, ISSN 0040-6031

Lindroos, A., Heinemeier, J., Ringbom, Å., Braskén, M. \& Sveinbjörnsdóttir, Á. (2007). Mortar dating using AMS $14 \mathrm{C}$ and sequential dissolution: examples from medieval, nonhydraulic lime mortars from the Aland Islands, SW Finland, Radiocarbon, Vol. 49, No. 1, pp. 47-67, ISSN 0033-8222 
Machel, H. G., (2000). Application of cathodoluminescence to carbonate diagenesis, ISBN 3-54065987-0,

Marques, S. F., Ribeiro, R. A., Silva, L. M., Ferreira, V. M. \& Labrincha, J. A. (2006). Study of rehabilitation mortars: Construction of a knowledge correlation matrix, Cement and Concrete Research, Vol. 36, No. 10, pp. 1894-1902, ISSN 0008-8846

Marshall, D. J., (1988). Cathodoluminescence of geological materials, Allen \& Unwin, ISBN 0045520267 (alk. paper), Boston

Marzaioli, F., Lubritto, C., Nonni, S., Passariello, I., Capano, M. \& Terrasi, F. (2011). Mortar Radiocarbon Dating: Preliminary Accuracy Evaluation of a Novel Methodology, Analytical Chemistry, Vol. 83, No. 6, pp. 2038-2045, ISSN 0003-2700

Nawrocka, D., Michniewicz, J., Pawlyta, J. \& Pazdur, A. (2005). Application of radiocarbon method for dating of lime mortars, Geochronometria, Vol. 24, pp. 109-115, ISSN 17338387

Nawrocka, D., Czernik, J. \& Goslar, T. (2009). C-14 dating of carbonate mortars from Polish and Israeli sites, Radiocarbon, Vol. 51, No. 2, pp. 857-866, ISSN 0033-8222

Nawrocka, D. M., Michczynska, D. J., Pazdur, A. \& Czernik, J. (2007). Radiocarbon chronology of the ancient settlement in the Golan Heights area, Israel, Radiocarbon, Vol. 49, No. 2, pp. 625-637, ISSN 0033-8222

Ortega, L. A., Zuluaga, M. C., Alonso-Olazabal, A., Insausti, M. \& Ibañez, A. (2008). Geochemical characterization of archaeological lime mortars: Provenance inputs, Archaeometry, Vol. 50, pp. 387-408, ISSN 0003-813X

Paama, L., Pitkanen, I., Ronkkomaki, H. \& Peramaki, P. (1998). Thermal and infrared spectroscopic characterization of historical mortars, Thermochimica Acta, Vol. 320, No. 1-2, pp. 127-133, ISSN 0040-6031

Pachiaudi, C., Marechal, J., Van Strydonck, M., Dupas, M. \& Dauchotdehon, M. (1986). Isotopic fractionation of carbon during CO2 absorption by mortar, Radiocarbon, Vol. 28, No. 2A, pp. 691-697, ISSN 0033-8222

Pagel, M., (2000). Cathodoluminescence in geosciences, Springer, ISBN 3540659870, Berlin

Rech, J. A., Fischer, A. A., Edwards, D. R. \& Jull, A. J. T. (2003). Direct dating of plaster and mortar using AMS radiocarbon: A pilot project from Khirbet Qana, Israel, Antiquity, Vol. 77, No. 295, pp. 155-164, ISSN 0003-598X

Rech, J. A. (2004). New uses for old laboratory techniques, Near Eastern Archaeology, Vol. 67, No. 4, pp. 212-219, ISSN 1094-2076

Reimer, P. J., Baillie, M. G. L., Bard, E., Bayliss, A., Beck, J. W., Blackwell, P. G., Ramsey, C. B., Buck, C. E., Burr, G. S., Edwards, R. L., Friedrich, M., Grootes, P. M., Guilderson, T. P., Hajdas, I., Heaton, T. J., Hogg, A. G., Hughen, K. A., Kaiser, K. F., Kromer, B., McCormac, F. G., Manning, S. W., Reimer, R. W., Richards, D. A., Southon, J. R., Talamo, S., Turney, C. S. M., van der Plicht, J. \& Weyhenmeye, C. E. (2009). IntCal09 and Marine09 radiocarbon age calibration curves, 0-50,000 years cal BP, Radiocarbon, Vol. 51, No. 4, pp. 1111-1150, ISSN 0033-8222

Salama, A. I. A. \& Ian, D. W., (2000). Mechanical techniques: particle size separation, in Encyclopedia of Separation Science pp. 3277-3289, Academic Press ISBN 978-0-12226770-3, Oxford

Schmid, S. G. (2001). The International Wadi Farasa Project IWF, preliminary report on the 1999 season, The Annual of the Department of Antiquities of Jordan, Vol. 45, pp. 343-357, ISSN 
Sickels, L. B., (1981). Organics vs. synthetics: their use as additives in mortars: Symposium on Mortars, Cements and Grouts Used in the Conservation of Historic Buildings, pp. 25-53.

Sonninen, E., Erametsa, P. \& Jungner, H., (1989). Dating of mortar and bricks: an example from Finland: Archaeometry: proceedings of the 25th international symposium pp. 99-107.

Sonninen, E. \& Jungner, H. (2001). An improvement in preparation of mortar for radiocarbon dating, Radiocarbon, Vol. 43, No. 2A, pp. 271-273, ISSN 0033-8222

Soukup, D. A., Buck, B. J. \& Harris, W., (2008). Preparing soils for mineralogical analyses, in Methods of Soil Analysis. Part 5-Mineralogical Methods, Ulery, A.L. \& Drees, L.R. (Eds.), pp. 12-31, Soil Science Society of America, Inc ISBN 978-0-89118-846-9, Madison

Stefanidou, M. \& Papayianni, I. (2005). The role of aggregates on the structure and properties of lime mortars, Cement and Concrete Composites, Vol. 27, No. 9-10, pp. 914-919, ISSN 0958-9465

Stokes, G. G. (1851). On the effect of the lateral friction of fluids on the motion of pendulums, Trans. Cambridge Phil. Soc., Vol. 9, pp. 8-108, ISSN

Stuiver, M. \& Smith, C. S., (1965). Radiocarbon dating of ancient mortar and plaster: Proceedings of the 6th International 14C Conference, pp. 338-343.

Tubbs, L. E. \& Kinder, T. N. (1990). The use of AMS for the dating of lime mortars, Nuclear Instruments and Methods in Physics Research Section B: Beam Interactions with Materials and Atoms, Vol. 52, No. 3-4, pp. 438, ISSN

Van Strydonck, M., Dupas, M. \& Dauchot-Dehon, M., (1983). Radiocarbon dating of old mortars: 14C and Archaeology, Proceedings, pp. 337-343.

Van Strydonck, M., Dupas, M., Dauchotdehon, M., Pachiaudi, C. \& Marechal, J. (1986). The influence of contaminating (fossil) carbonate and the variations of delta-C-13 in mortar dating, Radiocarbon, Vol. 28, No. 2A, pp. 702-710, ISSN 0033-8222

Van Strydonck, M. \& Dupas, M., (1991). The classification and dating of lime mortars by chemical analysis and radiocarbon dating: a review, in Second Deya International Conference of Prehistory : recent developments in western Mediterranean prehistory: archaeological techniques, technology, and theory, Waldren, W.H., Ensenyat, J.A. \& Kennard, R.C. (Eds.), pp. 5-43, Tempus Reparatum ISBN 0860547272, Oxford

Van Strydonck, M. J. Y., Van der Borg, K., De Jong, A. F. M. \& Keppens, E. (1992). Radiocarbon dating of lime fractions and organic material from buildings, Radiocarbon, Vol. 34, pp. 873-879, ISSN 0033-8222

Warkentin, B. P. \& Maeda, T., (1980). Physical and mechanical characteristics of andisols in Soils with Variable Charge, Theng, B.K.G. (Ed.), pp. 281-302, New Zealand Society of Soil Science ISBN Lower Hutt.

Wilson, R. \& Spengler, J. D., (1996). Particles in our air : concentrations and health effects, Harvard University Press, ISBN 0674240774, Cambridge, Mass

Wintle, A. G. (2008). Fifty years of luminescence dating*, Archaeometry, Vol. 50, No. 2, pp. 276312, ISSN 1475-4754

Wyrwa, A. M., Goslar, T. \& Czernik, J. (2009). AMS C-14 dating of romanesque rotunda and stone buildings of a medieval monastery in Lekno, Poland, Radiocarbon, Vol. 51, No. 2, pp. 471-480, ISSN 0033-8222

Zamba, I. C., Stamatakis, M. G., Cooper, F. A., Themelis, P. G. \& Zambas, C. G. (2007). Characterization of mortars used for the construction of Saithidai Heroon Podium (1st century AD) in ancient Messene, Peloponnesus, Greece, Materials Characterization, Vol. 58, No. 11-12, pp. 1229-1239, ISSN 1044-5803 


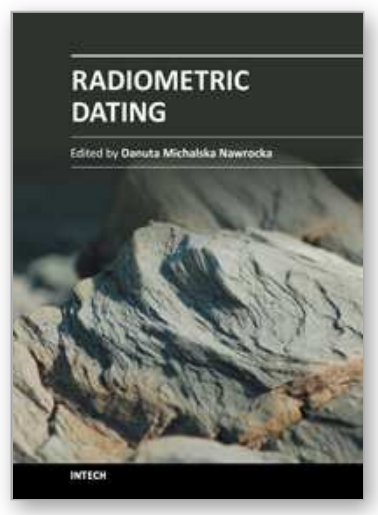

\author{
Radiometric Dating \\ Edited by Dr. Danuta Michalska Nawrocka
}

ISBN 978-953-51-0596-1

Hard cover, 126 pages

Publisher InTech

Published online 09, May, 2012

Published in print edition May, 2012

This book explores a diversity of topics related to radiometric dating, with particular emphasis on the method of radiocarbon dating and a cross-check of its results with luminescence measurements. Starting from the chapter on Methodology the book includes, among other topics, the description of the problem of preparation of samples for $14 \mathrm{C}$ measurement, a wide application of the radiocarbon method and a comparison of results obtained by various methods, including the radiocarbon method, the method of OSL, TL and palynology. The issue of radiocarbon dating of mortars and plasters is thoroughly discussed in the book. Chapter Two, Applications, and Three, Luminescence and Radiocarbon Measurements, provide examples of the application of the radiocarbon method in the study of archaeological, geological sites, from the analysis of soils, loesses, to the study of organic deposits filling the depressions in the Morasko Meteorite Nature Reserve. A wide range of studies reveals the great potential of the radiocarbon method, and the presented papers reflect interdisciplinary research.

\title{
How to reference
}

In order to correctly reference this scholarly work, feel free to copy and paste the following:

Luis Angel Ortega, Maria Cruz Zuluaga, Ainhoa Alonso-Olazabal, Maite Insausti, Xabier Murelaga and Alex Ibañez (2012). Improved Sample Preparation Methodology on Lime Mortar for Reliable 14C Dating, Radiometric Dating, Dr. Danuta Michalska Nawrocka (Ed.), ISBN: 978-953-51-0596-1, InTech, Available from: http://www.intechopen.com/books/radiometric-dating/improved-sample-preparation-methodology-on-limemortar-for-reliable-14-c-dating

\section{INTECH}

open science | open minds

\section{InTech Europe}

University Campus STeP Ri

Slavka Krautzeka 83/A

51000 Rijeka, Croatia

Phone: +385 (51) 770447

Fax: +385 (51) 686166

www.intechopen.com

\section{InTech China}

Unit 405, Office Block, Hotel Equatorial Shanghai

No.65, Yan An Road (West), Shanghai, 200040, China 中国上海市延安西路65号上海国际贵都大饭店办公楼 405 单元

Phone: +86-21-62489820

Fax: $+86-21-62489821$ 
(C) 2012 The Author(s). Licensee IntechOpen. This is an open access article distributed under the terms of the Creative Commons Attribution 3.0 License, which permits unrestricted use, distribution, and reproduction in any medium, provided the original work is properly cited. 